FINANSIA: Jurnal Akuntansi dan Perbankan

Syariah P-ISSN: 2621-4636; E-ISSN: 2621-4644

Volume 02, Nomor 01, Januari-Juni 2019

Website: www.febi.metrouniv.ac.id; E-mail:

jurnalfinansia@gmail.com

\title{
APLIKASI SINGLE INDEX MODEL DALAM PEMBENTUKAN PORTOFOLIO OPTIMAL SAHAM LQ45 PADA BURSA EFEK INDONESIA
}

\author{
Atika Lusi Tania \\ Fakultas Ekonomi dan Bisnis Islam IAIN Metro \\ Email:atikalusitania@gmail.com
}

\begin{tabular}{l|l|l} 
Diterima: Maret 2019 & Direvisi : Mei 2019 & Diterbitkan: Juni 2019 \\
\hline
\end{tabular}

\begin{abstract}
Single Index Model is a stock return model that divides the effect on returns into a systematic factor (as measured by yields on the market index) and company-specific factors. The shares used in the formation of the portfolio of the Single Index Model are stocks included in the LQ45 Index in the Indonesia Stock Exchange because this Index has always increased from year to year. However, not all shares in the LQ45 Index can be used, there must be a determination to get the most suitable shares to be used as a portfolio. Therefore, the author uses the Single Index Model Application in the Formation of the LQ45 Optimal Stock Porffolio on the Indonesia Stock. Exchange so that investors know how to form an optimal portfolio using a simpler model of the single index model. This study aims to apply the application of a single index model in the formation of a stock portfolio registered in LQ45, determine the proportion of stock investment in the number of lots based on the proportion of stock portfolios, and determine the funds needed for stock investment based on the number of lots. Based on the results of data analysis using the Single Index Model Optimal Portfolio, the results show that out of 45 stocks in LQ45, 13 optimal stocks will be purchased by investors. Thirteen shares and market prices include LPPF Rp.3,400, INTP Rp20,025, LPKR Rp274, INCO Rp3,030, PTPP Rp.2,180, SCMA Rp1,615, TBIG Rp.3,850, AALI Rp.10,350, CTRA Rp1. 070, PWON Rp725, TAXI Rp50, WIKA Rp2,340, and WSKT Rp1,970. The proportion of shares is 9\% LPPF, 7\% INTP, 5\% LPKR, 13\% INCO, 19\% PTPP, 12\% SCMA, 9\% TBIG, 7\% AALI, 4\% CTRA, $6 \%$ PWON, 3\% TAXI, 4\% WIKA, WSKT 2\%. The funds to be invested are IDR 1,000,000, the total number of shares to be purchased is 1,271 sheets, or if in the lot lot there are around 12 lots.
\end{abstract}

Keywords: optimal portfolio, single index model, proportion of shares. 


\begin{abstract}
Abtrak: Model Indeks Tunggal (Single Index Model) adalah model imbal hasil saham yang membagi pengaruh pada imbal hasil menjadi faktor sistematis (sebagaimana diukur dengan imbal hasil atas indeks pasar) dan faktor spesifik perusahaan. Sahamsaham yang digunakan dalam pembentukan portofolio Model Indeks Tunggal ini adalah saham-saham yang masuk dalam Indeks LQ45 yang ada di dalam Bursa Efek Indonesia karena Indeks ini selalu mengalami kenaikan dari tahun ke tahun. Namun tidak semua saham di dalam Indeks LQ45 dapat digunakan, harus ada penentuan untuk mendapatkan saham-saham yang paling cocok untuk dijadikan portofolio. Maka dari itu, penulis menggunakan Aplikasi Single Index Model dalam Pembentukan Portofolio Optimal Saham LQ45 pada Bursa Efek Indonesia agar para investor tahu bagaimana cara membentuk portofolio yang optimal dengan menggunakan model yang lebih sederhana yaitu model indeks tunggal. Penelitian ini bertujuan menerapkan aplikasi model indeks tunggal dalam pembentukan portofolio saham yang terdaftar pada LQ45, menentukan proporsi investasi saham ke dalam jumlah lot berdasarkan proporsi portofolio saham, dan menentukan dana yang dibutuhkan untuk investasi saham berdasarkan jumlah lot. Berdasarkan hasil analisis data menggunakan Portofolio Optimal metode Single Index Model, diperoleh hasil bahwa dari 45 saham dalam LQ45 diperoleh 13 saham optimal yang akan dibeli oleh investor. Tiga belas saham dan harga pasar tersebut antara lain LPPF Rp3.400, INTP Rp20.025, LPKR Rp274, INCO Rp3.030, PTPP Rp2.180, SCMA Rp1.615, TBIG Rp3.850, AALI Rp10.350, CTRA Rp1.070, PWON Rp725, TAXI Rp50, WIKA Rp2.340, dan WSKT Rp1.970. Proporsi saham yaitu LPPF 9\%, INTP 7\%, LPKR 5\%, INCO 13\%, PTPP $19 \%$, SCMA $12 \%$, TBIG $9 \%$, AALI 7\%, CTRA 4\%, PWON 6\%, TAXI 3\%, WIKA 4\%, WSKT 2\%. Dana yang akan diinvestasikan Rp 1.000.000, maka jumlah lembar saham total yang akan dibeli adalah 1.271 lembar, atau jika dalam jumlah lot sekitar 12 lot.
\end{abstract}

Kata kunci: portofolio optimal, single index model, proporsi saham.

\title{
A. LATAR BELAKANG
}

Investasi dalam bentuk saham diperkirakan semakin menarik investor. Dari data Kustodian Sentra Efek Indonesia (KSEI) per Maret 2018, jumlah investor pasar modal sudah mencapai 1,21 juta single investor identification (SID). Angka tersebut meningkat sebesar 8,34\% secara year to date (ytd) jika dibandingkan dengan akhir 2017 yaitu sejumlah 1,12 juta SID. Sementara, secara year on year (yoy) pertumbuhan investor mencapai 26,54\% per Maret 2018. Secara umur, investor dengan usia di bawah 20 mencapai 2,84\%. Sementara investor dengan rentang usia antara 21-30 tahun mencapai 32,67\% dari total investor. Investor yang berusia antara 31-40 tahun sekitar $24,59 \%$ dari total investor. ${ }^{1}$

\footnotetext{
${ }^{1}$ Mediatama, "Investor pasar modal per Maret 2018 meningkat 8,34\%.”
} 
Atika Lusi Tania

Aplikasi Single Index Model.....

Pada kawasan ASEAN per tanggal 9 Juli 2018, Indeks Harga Saham Gabungan Indonesia (JCI) tergolong yang tertinggi yaitu sebesar 5.807,38; Indeks FTSE BM Malaysia menunjukkan angka 1.672,63; indeks STI Singapure menunjukkan angka 3.228,82; indeks SETi Thailand menunjukkan angka 1.662,96 dan VN-Index Vietnam menunjukkan angka 915,12. Hal ini menunjukkan bahwa investasi saham di Indonesia cukup menarik investor. ${ }^{2}$

Investasi dalam bentuk saham memang memiliki risiko yang lebih tinggi jika dibandingkan dengan investasi pada aktiva lainnya. Namun, investor tidak perlu menghawatirkan tingginya risiko tersebut. Bagian dari risiko sekuritas ada yang dapat dihilangkan yaitu risiko dapat di-diversifikasi dengan membentuk portofolio yang welldiversified. ${ }^{3}$

Portofolio juga mempunyai kepekaan terhadap populasi saham yang diambil. Keuntungan membentuk portofolio dapat dicapai dengan sekuritas yang tidak terlalu banyak. Namun, ada pula yang justru semakin banyak sekuritas yang dimasukkan ke dalam portofolio, semakin kecil risiko portofolio. Oleh karena itulah diperlukan suatu metoda dalam menentukan populasi saham yang akan masuk dalam portofolio agar menghasilkan portofolio yang optimal. Perhitungan portofolio dengan Metode Markowitz dianggap cukup rumit karena melibatkan banyak varian dan kovarian. Willian Sharpe (1963) mengembangkan model yang disebut dengan model indeks tunggal (Single-index model) ${ }^{4}$. Model ini digunakan untuk menyederhanakan perhitungan di model Markowitz.

Model Indeks Tunggal (Single Index Model) adalah model imbal hasil saham yang membagi pengaruh pada imbal hasil menjadi faktor sistematis (sebagaimana diukur dengan imbal hasil atas indeks pasar) dan faktor spesifik perusahaan. Saham-saham yang digunakan dalam pembentukan portofolio Model Indeks Tunggal ini adalah saham-saham yang masuk dalam Indeks LQ45 yang ada di dalam Bursa Efek Indonesia karena Indeks ini selalu mengalami kenaikan

\footnotetext{
2 "PT Bursa Efek Indonesia."

${ }^{3}$ Hartono, Teori Portofolio Dan Analisis Investasi (Edisi Kedelapan).

${ }^{4}$ Hartono, Teori Dan Praktik Portofolio Dengan Excel.
} 
dari tahun ke tahun. Namun tidak semua saham di dalam Indeks LQ45 dapat digunakan, harus ada penentuan untuk mendapatkan sahamsaham yang paling cocok untuk dijadikan portofolio. Maka dari itu, penulis menggunakan Aplikasi Single Index Model dalam Pembentukan Portofolio Optimal Saham LQ45 pada Bursa Efek Indonesia agar para investor tahu bagaimana cara membentuk portofolio yang optimal dengan menggunakan model yang lebih sederhana yaitu model indeks tunggal.

Setelah diperoleh proporsi saham optimal menggunakan model indeks tunggal, maka dapat ditentukan pula proporsi investasi saham ke dalam jumlah lot. Selanjutnya setelah jumlah lot diketahui, dapat ditentukan berapa dana yang diperlukan untuk investasi saham secara optimal. Populasi dan sekaligus sampel dari penelitian ini adalah saham-saham yang terdaftar dalam indeks LQ45.

Penelitian sebelumnya yang dilakukan oleh Septyanto dan Kertopati ${ }^{5}$ untuk menganalisa pembentukan portofolio saham dengan model Markowitz dan Single Index Model pada saham-saham yang terdaftar pada LQ45. Hasil penelitian menunjukkan bahwa perhitungan portofolio yang paling efisien adalah menggunakan perhitungan Single Index Model. Hal ini dukung oleh teori yang menyatakan bahwa Portofolio yang efisien adalah portofolio yang dapat memberikan return ekspektasian terbesar dengan resiko yang tertentu atau memberikan resiko terkecil dengan return ekspektasian tertentu. Perhitungan Single Index Model memberikan expected return terbesar (0,596\%) dengan resiko terkecil $(0,0264 \%)$.

Selain itu, penelitian oleh Oktaviani dan Wijayanto ${ }^{6}$ yang berjudul aplikasi Single Index Model dalam pembentukan portofolio optimal saham LQ45 dan Jakarta Islamic Index, menunjukkan hasil bahwa melakukan diversifikasi dengan model indeks tunggal terbukti lebih baik dan menguntungkan dilihat dari kinerja portfofolio yang dibandingkan dengan kinerja IHSG. Saran yang berkaitan dengan

\footnotetext{
${ }^{5}$ Septyanto and Kertopati, "Portofolio Saham Dengan Model Markowitz Dan Single Index Model Pada Saham-Saham Yang Terdaftar Pada LQ45."

${ }^{6}$ Oktaviani and Wijayanto, "Aplikasi Single Index Model Dalam Pembentukan Portofolio Optimal Saham LQ45 Dan Jakarta Islamic Index."
} 
penelitian yaitu investor konvensional dapat memilih portofolio LQ45 dan investor dengan investasi syariah dapat memilih portofolio JII yang dibentuk.

\section{B. LANDASAN TEORI}

\section{Hubungan antara Return dan Risiko}

Return dan risiko merupakan dua hal yang tidak terpisah, karena pertimbangan suatu investasi merupakan trade-off dari kedua faktor ini. Return dan risiko mempunyai hubungan yang positif, semakin besar risiko yang harus ditanggung, semakin besar return yang harus dikompensasikan. Untuk melakukan analisis investasi, dua faktor harus dipertimbangkan bersama-sama, yaitu return ekspektasian dan risiko aktiva. Koefisien variasi (coefficient of variation) dapat digunakan untuk mempertimbangkan dua faktor tersebut bersamaan.

\section{Portofolio Optimal}

Investor harus cerdas dalam membuat portfolio. Portofolio harus mencakup berbagai diversifikasi saham internasional dari berbagai benua dan dari maju dan negara berkembang dengan berbagai tingkat pasar saham. Menurut Valadkhani et al.

"if the aim of an astute investor is to reduce systematic investment risk across countries, his or her financial portfolio should include a diversified range of international stocks from various continents and from both developed and developing countries with varying degrees of stock market maturities." 7

Portofolio-portofolio efisien belum berupa portofolio optimal. Portofolio efisien adalah portofolio yang baik, tetapi belum terbaik. Portofolio efisien hanya mempunyai satu faktor yang baik, yaitu faktor return ekspektasian atau faktor risikonya, belum terbaik keduanya. Portofolio optimal merupakan portofolio dengan kombinasi return ekspektasian dan risiko terbaik.

\footnotetext{
${ }^{7}$ Abbas, Chancharat, and Harvie, "A Factor Analysis of International Portfolio Diversification."
} 


\section{Teori Perhitungan Model Indeks Tunggal ${ }^{8}$}

Model Indeks Tunggal (Single Index Model) adalah model imbal hasil saham yang membagi pengaruh pada imbal hasil menjadi faktor sistematis (sebagaimana diukur dengan imbal hasil atas indeks pasar) dan faktor spesifik perusahaan. Single Index Model merupakan analisis yang dikembangkan oleh William Sharpe pada tahun 1963. Single Index Model merupakan penyederhanaan dari teori model Markowitz yang memperkecil input analisis teori portofolio dan mereduksi jumlah variabel yang perlu ditaksir, disamping itu model ini juga dapat digunakan untuk menghitung return ekspektasi dan resiko portofolio. Menurut Jogiyanto (2008), menentukan portofolio yang optimal akan lebih mudah jika didasarkan pada sebuah angka yang dapat menentukan apakah suatu sekuritas dapat dimasukan ke dalam portofolio optimal tersebut. Angka yang dimaksud adalah rasio antara ekses return dengan Beta (excess return to beta ratio) dengan perhitungan rasio sebagai berikut:

$$
E R B_{i}=\frac{E\left(R_{i}\right)-R_{B R}}{\beta_{i}}
$$

$E R B_{i}$ : excess return to beta sekuritas ke-i

$E\left(R_{i}\right)$ : return ekspektasian berdasarkan Single Index Model untuk sekuritas ke-i

$R_{B R}$ : return aktiva bebas risiko

$\beta_{i}$ : beta sekuritas ke-i

Portofolio yang optimal akan berisikan dengan aktiva-aktiva yang mempunyai nilai rasio ERB yang tinggi. Aktiva-aktiva dengan rasio ERB rendah tidak akan dimasukan kedalam sebuah titik pembatas (cut-off point) yang menentukan batas nilai ERB berapa yang dikatakan tinggi. Menurut Jogiyanto (2008), ada beberapa cara untuk menentukan titik pembatas ini yaitu:

a. Mengurutkan saham-saham berdasarkan nilai ERB terbesar ke nilai ERB terkecil yang merupakan kandidat untuk dimasukan ke portofolio optimal.

${ }^{8}$ Hartono, Teori Dan Praktik Portofolio Dengan Excel. 
b. Menghitung nilai Ai dan Bi untuk masing-masing saham ke-I sebagai berikut :

$A_{i}=\frac{\left[E\left(R_{i}\right)-R_{B R}\right] \cdot \beta_{i}}{\sigma_{e i}^{2}}$

Dan

$B_{i}=\frac{\beta_{i}^{2}}{\sigma_{e i}^{2}}$

$E\left(R_{i}\right)$ : return ekspektasian berdasarkan Single Index Model untuk sekuritas ke-i

$R_{B R}$ : return aktiva bebas risiko

$\beta_{i}$ : beta sekuritas ke-i

$\sigma_{e i}^{2}$ : varian dari kesalahan residu sekuritas ke-i yang juga merupakan risiko unik atau risiko tidak sistematis

c. Menghitung nilai C1 dengan rumus sebagai berikut:

$$
C_{1}=\frac{\sigma_{m}^{2} \sum_{j=1}^{i} A_{j}}{1+\sigma_{m}^{2} \sum_{j=1}^{i} B_{j}}
$$

$C_{1}$ : Cut-off rate

$\sigma^{2}$ : Varian dari return indeks pasar

$B_{j}$ : Beta saham ke-i

d. Besarnya cut-offpoint ( $C^{*}$ ) adalah nilai C1 dimana nilai ERB terakhir kali masih lebih besar dari nilai $\mathrm{C} 1$.

e. Saham-saham yang membentuk portofolio optimal yaitu saham-saham yang mempunyai nilai ERB di titik C*. Sahamsaham yang mempunyai ERB lebih kecil dengan ERB titik $\mathrm{C}^{*}$ tidak diikutsertakan dalam pembentukan portofolio optimal. 
f. Setelah saham-saham yang membentuk portofolio optimal telah dapat ditentukan, maka selanjutnya adalah menentukan proporsi dana untuk masing-masing saham yang membentuk portofolio. Investor dapat menentukan proporsi masingmasing saham tersebut dalam portofolio optimal. Adapun proporsi untuk saham ke-i adalah:

$$
W i=\frac{Z_{i}}{\sum_{j=1}^{k} Z_{j}}
$$

Dengan Zi adalah:

$Z i=\frac{\beta_{i}}{\sigma_{a i}^{2}}\left(E R B_{i}-C^{*}\right)$

Keterangan:

Wi: proporsi aktiva ke-i

k: jumlah aktiva di portofolio optimal

$\beta_{i}$ : beta aktiva ke-i

$\sigma_{e i}^{2}$ : varian dari kesalahan residu aktiva ke-i

$E R B_{i}$ : excess return to beta aktiva ke-i

$C^{*}$ : nilai cut-off point yang merupakan nilai Ci terbesar

Penelitian ini membahas mengenai saham-saham dalam Indeks LQ45 untuk dibentuk menjadi portofolio optimal dengan menggunakan Model Indeks Tunggal. Selanjutnya menentukan proporsi investasi saham ke dalam jumlah lot berdasarkan proporsi portofolio saham dan terakhir menentukan dana yang dibutuhkan untuk investasi saham berdasarkan jumlah lot. Maka jenis penelitian ini adalah penelitian deskriptif dengan pendekatan kuantitatif. Dengan menggunakan sebagai berikut. 
Atika Lusi Tania

Aplikasi Single Index Model.....

1. Harga penutupan harian historis saham-saham yang masuk dalam indeks LQ45 tanggal 1 Januari 2013 sampai dengan 26 Agustus 2014.

2. Indeks Harga Saham Gabungan (IHSG) selama periode pengamatan. Data ini diperlukan untuk mencari return market.

3. Tingkat suku bunga Sertifikat Bank Indonesia (SBI) selama periode pengamatan. Data ini diperlukan untuk mencari Return Bebas Risiko.

\section{PEMBAHASAN}

\section{Data Harga Saham}

Harga penutupan harian saham yang diperoleh adalah selama 431 hari mulai dari 1 Januari 2013 sampai dengan 26 Agustus 2014. Saham-saham perusahaan yang terdaftar dalam indeks LQ45 terdiri dari 45 perusahaan berikut:

Tabel 1. Daftar saham perusahaan LQ45

\begin{tabular}{|l|l|l|}
\hline No. & Nama Emiten LQ45 & Kode \\
\hline 1 & PT Astra Agro Lestari Tbk & AALI \\
\hline 2 & PT Adhi Karya (Persero) Tbk & ADHI \\
\hline 3 & PT Adaro Energy Tbk & ADRO \\
\hline 4 & PT AKR Corporindo & AKRA \\
\hline 5 & PT Aneka Tambang Tbk & ANTM \\
\hline 6 & PT Astra International Tbk & ASII \\
\hline 7 & PT Alam Sutera Realty Tbk & ASRI \\
\hline 8 & PT Bank Central Asia Tbk & BBCA \\
\hline 9 & PT Bank Negara Indonesia Tbk & BBNI \\
\hline 10 & PT Bank Rakyat Indonesia Tbk & BBRI \\
\hline 11 & PT Bank Tabungan Negara Tbk & BBTN \\
\hline 12 & PT Bank Danamon Tbk & BDMN \\
\hline 13 & PT Bank Mandiri Tbk & BMRI \\
\hline
\end{tabular}




\begin{tabular}{|l|l|l|}
\hline 14 & PT Global Mediacom Tbk & BMTR \\
\hline 15 & PT Bumi Serpong Damai Tbk & BSDE \\
\hline 16 & PT Charoen Pokphand Indonesia Tbk & CPIN \\
\hline 17 & PT Ciputra Development Tbk & CTRA \\
\hline 18 & PT XL Axiata & EXCL \\
\hline 19 & PT Gudang Garam Tbk & GGRM \\
\hline 20 & PT Harum Energy Tbk & HRUM \\
\hline 21 & PT Indofood CBP Sukses Makmur Tbk & ICBP \\
\hline 22 & PT Indofood Sukses Makmur Tbk & INDF \\
\hline 23 & PT Vale Indonesia Tbk & INCO \\
\hline 24 & PT Indocement Tunggal Prakarsa Tbk & INTP \\
\hline 25 & PT Indo Tambangraya Megah Tbk & ITMG \\
\hline 26 & PT Jasa Marga Tbk & JSMR \\
\hline 27 & PT Kalbe Farma Tbk & KLBF \\
\hline 28 & PT Lippo Karawaci Tbk & LPKR \\
\hline 29 & PT Matahari Department Store Tbk & LPPF \\
\hline 30 & PT PP London Sumatra Indonesia Tbk & LSIP \\
\hline 31 & PT Media Nusantara Citra Tbk & MNCN \\
\hline 32 & PT Perusahaan Gas Negara Tbk & PGAS \\
\hline 33 & PT Tambang Batubara Bukit Asam Tbk & PTBA \\
\hline 34 & PT PP (Persero) Tbk & PTPP \\
\hline 35 & PT Pakuwon Jati Tbk & PWON \\
\hline 36 & PT Surya Citra Media Tbk & SCMA \\
\hline 37 & PT Semen Indonesia (Persero) Tbk & \\
\hline 38 & PT Summarecon Agung Tbk & PT Express Transindo Utama Tbk \\
\hline 39 & & TMGR \\
\hline
\end{tabular}




\begin{tabular}{|l|l|l|}
\hline 40 & PT Tower Bersama Infrastructure Tbk & TBIG \\
\hline 41 & PT Telekomunikasi Indonesia Tbk & TLKM \\
\hline 42 & PT United Tractors Tbk & UNTR \\
\hline 43 & PT Unilever Indonesia Tbk & UNVR \\
\hline 44 & PT Wijaya Karya (Persero) Tbk & WIKA \\
\hline 45 & PT Waskita Karya (Persero) Tbk & WSKT \\
\hline
\end{tabular}

\section{Return Ekspektasian Saham, Risiko dan Coeficience of} Variance

Return Ekpektasian Saham merupakan return yang diperoleh dari perhitungan rata-rata harga saham harian selama 431 hari. Resiko diperoleh dengan menggunakan perhitungan standar deviasi dari harga saham harian selama 431 hari. Sedangkan Coeficience of variance diperoleh dengan membagi resiko dan return ekspektasian. Berdasarkan olah data diperoleh hasil sebagai berikut.

Tabel 2. Hasil Perhitungan Return Ekspektasian, Risiko, dan Coeficience of Variance

\begin{tabular}{|l|l|l|r|r|}
\hline No & \multicolumn{1}{|c|}{$\begin{array}{c}\text { Kode } \\
\text { Saham }\end{array}$} & Risk & $\begin{array}{c}\text { Expected } \\
\text { Return }\end{array}$ & \multicolumn{1}{c|}{$\begin{array}{c}\text { Coeficience of } \\
\text { Variance }\end{array}$} \\
\hline 1 & AALI & 0,0227 & 0,0010 & 23,6722 \\
\hline 2 & ADHI & 0,0327 & 0,0018 & 18,4235 \\
\hline 3 & ADRO & 0,0288 & $-0,0001$ & $-245,8842$ \\
\hline 4 & AKRA & 0,0256 & 0,0008 & 31,6118 \\
\hline 5 & ANTM & 0,0245 & 0,0001 & 194,6797 \\
\hline 6 & ASII & 0,0215 & 0,0002 & 87,9035 \\
\hline 7 & ASRI & 0,0340 & 0,0001 & $24,4,4046$ \\
\hline 8 & BBCA & 0,0181 & 0,0007 & 17,1734 \\
\hline 9 & BBNI & 0,0224 & 0,0011 & $-98,8809$ \\
\hline 10 & BBRI & 0,0232 & 0,0014 & $-28,1492$ \\
\hline 11 & BBTN & 0,0261 & $-0,0003$ & 28,0582 \\
\hline 12 & BDMN & 0,0205 & $-0,0007$ & $-799,4298$ \\
\hline 13 & BMRI & 0,0228 & 0,0008 & 21,5721 \\
\hline 14 & BMTR & 0,0275 & 0,0000 & \\
\hline 15 & BSDE & 0,0281 & 0,0013 & \\
\hline
\end{tabular}




\begin{tabular}{|c|c|c|c|c|}
\hline 16 & CPIN & 0,0305 & 0,0008 & 38,2805 \\
\hline 17 & CTRA & 0,0339 & 0,0015 & 23,1128 \\
\hline 18 & EXCL & 0,0233 & 0,0003 & 82,9781 \\
\hline 19 & GGRM & 0,0203 & 0,0001 & 186,4693 \\
\hline 20 & HRUM & 0,0269 & $-0,0019$ & $-13,8661$ \\
\hline 21 & ICBP & 0,0212 & 0,0008 & 27,2837 \\
\hline 22 & INDF & 0,0198 & 0,0006 & 32,3133 \\
\hline 23 & INCO & 0,0300 & 0,0018 & 16,9567 \\
\hline 24 & INTP & 0,0234 & 0,0005 & 45,3586 \\
\hline 25 & ITMG & 0,0235 & $-0,0006$ & $-36,7718$ \\
\hline 26 & JSMR & 0,0193 & 0,0005 & 37,3193 \\
\hline 27 & $\mathrm{KLBF}$ & 0,0221 & 0,0014 & 16,2424 \\
\hline 28 & LPKR & 0,0266 & 0,0006 & 43,2411 \\
\hline 29 & LPPF & 0,0831 & 0,0061 & 13,5284 \\
\hline 30 & LSIP & 0,0277 & 0,0000 & $-2552,5760$ \\
\hline 31 & MNCN & 0,0297 & 0,0008 & 37,4474 \\
\hline 32 & PGAS & 0,0219 & 0,0009 & 24,2456 \\
\hline 33 & PTBA & 0,0270 & 0,0001 & 358,4746 \\
\hline 34 & PTPP & 0,0344 & 0,0031 & 11,0580 \\
\hline 35 & PWON & 0,0325 & 0,0021 & 15,5212 \\
\hline 36 & SCMA & 0,0268 & 0,0017 & 16,1846 \\
\hline 37 & SMGR & 0,0225 & 0,0004 & 62,2627 \\
\hline 38 & SMRA & 0,0396 & 0,0001 & 670,1842 \\
\hline 39 & TAXI & 0,0316 & 0,0015 & 20,6515 \\
\hline 40 & TBIG & 0,0208 & 0,0009 & 23,3167 \\
\hline 41 & TLKM & 0,0431 & $-0,0008$ & $-53,4432$ \\
\hline 42 & UNTR & 0,0232 & 0,0006 & 38,0909 \\
\hline 43 & UNVR & 0,0227 & 0,0012 & 19,0992 \\
\hline 44 & WIKA & 0,0315 & 0,0020 & 16,0713 \\
\hline 45 & WSKT & 0,0326 & 0,0021 & 15,5216 \\
\hline
\end{tabular}

\section{Return Market}

Return Market merupakan return yang diperoleh dari data IHSG selama 431 hari. Rumus yang digunakan dalam perhitungan return market adalah rata-rata dari data IHSG selama 431 hari. Hasil perhitungan return market menunjukkan angka sebesar 0,00048.

\section{Return Bebas Risiko}


Return bebas risiko merupakan return yang diperoleh dari data BI rate. Hasil perhitungan menunjukkan angka BI Rate sebesar $6,87 \%$.

Tabel 3. BI Rate mulai 1 Januari 2013 sampai dengan 26 Agustus 20149

\begin{tabular}{|l|r|}
\hline Tanggal & BI Rate \\
\hline 14 Agustus 2014 & $7,50 \%$ \\
\hline 10 Juli 2014 & $7,50 \%$ \\
\hline 12 Juni 2014 & $7,50 \%$ \\
\hline 8 Mei 2014 & $7,50 \%$ \\
\hline 08 April 2014 & $7,50 \%$ \\
\hline 13 Maret 2014 & $7,50 \%$ \\
\hline 13 Februari 2014 & $7,50 \%$ \\
\hline 9 Januari 2014 & $7,50 \%$ \\
\hline 12 Desember 2013 & $7,50 \%$ \\
\hline 12 Nopember 2013 & $7,50 \%$ \\
\hline 8 Oktober 2013 & $7,25 \%$ \\
\hline 12 September 2013 & $7,25 \%$ \\
\hline 29 Agustus 2013 & $7,00 \%$ \\
\hline 15 Agustus 2013 & $6,50 \%$ \\
\hline 11 Juli 2013 & $6,50 \%$ \\
\hline 13 Juni 2013 & $6,00 \%$ \\
\hline 14 Mei 2013 & $5,75 \%$ \\
\hline 11 April 2013 & $5,75 \%$ \\
\hline 7 Maret 2013 & $5,75 \%$ \\
\hline 12 Februari 2013 & $5,75 \%$ \\
\hline 10 Januari 2013 & $5,75 \%$ \\
\hline RATA RATA GEOMETRIK & $\mathbf{6 , 8 7 \%}$ \\
\hline
\end{tabular}

\section{Input}

Input merupakan proses memasukkan data return ekspektasian saham, risiko saham, return market dan risiko market. Data tersebut digunakan untuk mencari beta aktiva ke-i. Kemudian data return ekspektasian, beta ke-i, dan retun ekspektasian digunakan untuk mencari Alfa aktiva ke-i. Data beta aktiva ke-i dan

9 “BI 7-Day Repo Rate Data - Bank Sentral Republik Indonesia." 
alfa aktiva ke-i digunakan untuk mencari varian dari kesalahan residu aktiva ke-i. Data return bebas risiko harian, return ekspektasian dan beta aktiva ke-i digunakan untuk mencari excess return to beta aktiva ke-i. Berdasarkan perhitungan tersebut diperoleh hasil sebagai berikut:

Tabel 4. Hasil input data mencari Excess Return to Beta Aktiva ke-i

\begin{tabular}{|c|c|c|c|c|c|c|c|}
\hline No & et & E(Ri) & $\Sigma \mathbf{i}$ & Bi & $\alpha \mathbf{i}$ & $\sigma \varepsilon i 2$ & ERBi \\
\hline 1 & LI & 000959 & 0,022665 & 0,548025 & 0,000697 & 0,000473 & 0,001551 \\
\hline 2 & HI & 0,001777 & 0,032704 & 629531 & 0,001001 & 0,000711 & 0,001024 \\
\hline 3 & $\mathbf{0}$ & 00012 & 0,02875 & 589 & $-0,00048$ & 0,00075 & $-0,0003$ \\
\hline 4 & RA & 00081 & 0,025583 & 1,027685 & 0,00032 & 0,000512 & 0,000683 \\
\hline 5 & & 0,000126 & 0,024474 & 445 & $-0,00023$ & 0,000524 & $2,3 \mathrm{E}-05$ \\
\hline 6 & & 0,000245 & 0,021475 & 225 & $-0,0004$ & 0,000214 & 0,0001 \\
\hline 7 & & 35 & 33952 & 1,792568 & $-0,00072$ & 0,000719 & $1,49 \mathrm{E}-05$ \\
\hline 8 & CA & 0,000742 & 0,018085 & 1,127629 & 0,000204 & 0,000156 & 0,000562 \\
\hline 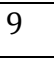 & 1 & 0,001064 & 0,022332 & 1,431417 & 0,000381 & 0,000222 & 0,000667 \\
\hline 10 & RI & 0,001351 & 0,023179 & 1,507434 & 0,000633 & 0,000231 & 0,000824 \\
\hline 11 & & 26 & 03 & 339 & 086 & 0,000464 & $-0,0003$ \\
\hline 12 & BDMN &, 00073 & 0,020454 & 0,670715 & $-0,00105$ & 0,000358 & $-0,00125$ \\
\hline 1. & & 000812 & 022748 & 899 & 0,000119 & 233 & 0,000484 \\
\hline 14 & $\mathrm{~B}$ & $4 \mathrm{E}-05$ & 0,027448 & ,27664 & $-0,00064$ & 0,000534 & $-0,00011$ \\
\hline 15 & DE &, 001304 & 0,0281 & 1,518852 & 0,00058 & 0,000478 & 0,000787 \\
\hline 16 & C & 96 & 42 & 541 & -06 & 541 & 0,000407 \\
\hline 17 & C & 65 & 82 & 759 & 998 & 014 & 0,001383 \\
\hline 18 & & 00281 & 0,023307 & 0,722038 & $-6,3 E-05$ & 0,000473 & 0,000239 \\
\hline 19 & G & 09 & 23 & 13 & 35 & 287 & 4,06E-07 \\
\hline 20 & & 194 & 876 & 454 & 217 &, 000692 & $-0,00434$ \\
\hline 21 & & 7 & 69 & 65 & 028 & 302 & 0,000641 \\
\hline 22 & II & 000613 & 01977 &, 911483 & 0,000178 & 0,000279 & 0,000553 \\
\hline 23 & & 7 & 22 & 34 & 98 & 815 & 0,002144 \\
\hline 24 & I & 00516 & 0,023396 & 0,113388 & 0,000462 & 0,000546 & 0,003595 \\
\hline 25 & & 00064 & 0,023519 & 0,605814 & $-0,00093$ & 0,000504 & $-0,00124$ \\
\hline 26 & & 7 & 7 & 54 & 36 & 71 & 07 \\
\hline 27 & & 0,001361 & 0,022073 & 1,20594 & 0,000786 & 0,000291 & 0,001038 \\
\hline 20 & & 16 & 26585 & 0,224664 & 0,000508 & 0,0007 & 0,002256 \\
\hline 2 & I & 006145 & 083033 & 51 & 0,005456 & 0,006613 & 0,004178 \\
\hline
\end{tabular}


Atika Lusi Tania

Aplikasi Single Index Model.....

\begin{tabular}{|l|l|r|r|r|r|r|r|}
\hline 30 & LSIP & $-1,1 \mathrm{E}-05$ & 0,02768 & 0,494453 & $-0,00025$ & 0,000733 & $-0,00024$ \\
\hline 31 & MNCN & 0,000792 & 0,029641 & 1,398949 & 0,000126 & 0,000615 & 0,000489 \\
\hline 32 & PGAS & 0,000902 & 0,021832 & 0,927605 & 0,000459 & 0,000361 & 0,000855 \\
\hline 33 & PTBA & $7,53 \mathrm{E}-05$ & 0,026958 & 0,743989 & $-0,00028$ & 0,000652 & $-4,5 \mathrm{E}-05$ \\
\hline 34 & PTPP & 0,003107 & 0,034319 & 1,715706 & 0,002289 & 0,000781 & 0,001748 \\
\hline 35 & PWON & 0,002097 & 0,032504 & 1,553138 & 0,001356 & 0,000731 & 0,00128 \\
\hline 36 & SCMA & 0,001658 & 0,026799 & 0,931893 & 0,001214 & 0,000601 & 0,001662 \\
\hline 37 & SMGR & 0,000361 & 0,022461 & 1,448072 & $-0,00033$ & 0,000222 & 0,000174 \\
\hline 38 & SMRA & $5,91 \mathrm{E}-05$ & 0,039555 & 1,487501 & $-0,00065$ & 0,001266 & $-3,3 \mathrm{E}-05$ \\
\hline 39 & TAXI & 0,001532 & 0,031592 & 1,130663 & 0,000993 & 0,000826 & 0,001258 \\
\hline 40 & TBIG & 0,000893 & 0,020796 & 0,487429 & 0,000661 & 0,0004 & 0,001609 \\
\hline 41 & TLKM & $-0,00081$ & 0,043085 & 0,965944 & $-0,00127$ & 0,00173 & $-0,00095$ \\
\hline 42 & UNTR & 0,000609 & 0,023158 & 1,064544 & 0,000101 & 0,000383 & 0,00047 \\
\hline 43 & UNVR & 0,001186 & 0,02263 & 1,189924 & 0,000619 & 0,000321 & 0,000906 \\
\hline 44 & WIKA & 0,001959 & 0,031441 & 1,55674 & 0,001217 & 0,000662 & 0,001188 \\
\hline 45 & WSKT & 0,002103 & 0,032606 & 1,793761 & 0,001248 & 0,000629 & 0,001112 \\
\hline
\end{tabular}

\section{Menghapus ERBi yang bernilai negatif}

Setelah diurutkan berdasarkan besarnya nilai excess return to beta aktiva ke-i, kemudian angka yang bernilai negatif dihilangkan, diperoleh sejumlah 34 saham dari sebelumnya 45 saham. Daftar 34 saham tersebut antara lain sebagai berikut:

Tabel 5. Daftar saham dengan nilai ERBi positif

\begin{tabular}{|l|l|l|l|r|l|l|r|}
\hline No & Ket. & ERBi & $\mathbf{E}(\mathbf{R i})$ & $\boldsymbol{\sigma}$ & $\boldsymbol{\beta} \mathbf{i}$ & $\boldsymbol{\alpha i}$ & \multicolumn{1}{|c|}{$\boldsymbol{\sigma \varepsilon i 2}$} \\
\hline 1 & LPPF & 0,004178 & 0,006145 & 0,083033 & 1,444751 & 0,005456 & 0,006613 \\
\hline 2 & INTP & 0,003595 & 0,000516 & 0,023396 & 0,113388 & 0,000462 & 0,000546 \\
\hline 3 & LPKR & 0,002256 & 0,000616 & 0,026585 & 0,224664 & 0,000508 & 0,0007 \\
\hline 4 & INCO & 0,002144 & 0,001767 & 0,029922 & 0,7734 & 0,001398 & 0,000815 \\
\hline 5 & PTPP & 0,001748 & 0,003107 & 0,034319 & 1,715706 & 0,002289 & 0,000781 \\
\hline 6 & SCMA & 0,001662 & 0,001658 & 0,026799 & 0,931893 & 0,001214 & 0,000601 \\
\hline 7 & TBIG & 0,001609 & 0,000893 & 0,020796 & 0,487429 & 0,000661 & 0,0004 \\
\hline 8 & AALI & 0,001551 & 0,000959 & 0,022665 & 0,548025 & 0,000697 & 0,000473 \\
\hline 9 & CTRA & 0,001383 & 0,001465 & 0,03382 & 0,980759 & 0,000998 & 0,001014 \\
\hline 10 & PWON & 0,00128 & 0,002097 & 0,032504 & 1,553138 & 0,001356 & 0,000731 \\
\hline 11 & TAXI & 0,001258 & 0,001532 & 0,031592 & 1,130663 & 0,000993 & 0,000826 \\
\hline
\end{tabular}




\begin{tabular}{|l|l|r|r|r|r|r|r|}
\hline 12 & WIKA & 0,001188 & 0,001959 & 0,031441 & 1,55674 & 0,001217 & 0,000662 \\
\hline 13 & WSKT & 0,001112 & 0,002103 & 0,032606 & 1,793761 & 0,001248 & 0,000629 \\
\hline 14 & KLBF & 0,001038 & 0,001361 & 0,022073 & 1,20594 & 0,000786 & 0,000291 \\
\hline 15 & ADHI & 0,001024 & 0,001777 & 0,032704 & 1,629531 & 0,001001 & 0,000711 \\
\hline 16 & UNVR & 0,000906 & 0,001186 & 0,02263 & 1,189924 & 0,000619 & 0,000321 \\
\hline 17 & PGAS & 0,000855 & 0,000902 & 0,021832 & 0,927605 & 0,000459 & 0,000361 \\
\hline 18 & BBRI & 0,000824 & 0,001351 & 0,023179 & 1,507434 & 0,000633 & 0,000231 \\
\hline 19 & BSDE & 0,000787 & 0,001304 & 0,0281 & 1,518852 & 0,00058 & 0,000478 \\
\hline 20 & AKRA & 0,000683 & 0,00081 & 0,025583 & 1,027685 & 0,00032 & 0,000512 \\
\hline 21 & BBNI & 0,000667 & 0,001064 & 0,022332 & 1,431417 & 0,000381 & 0,000222 \\
\hline 22 & ICBP & 0,000641 & 0,000777 & 0,021169 & 1,041765 & 0,00028 & 0,000302 \\
\hline 23 & BBCA & 0,000562 & 0,000742 & 0,018085 & 1,127629 & 0,000204 & 0,000156 \\
\hline 24 & INDF & 0,000553 & 0,000613 & 0,01977 & 0,911483 & 0,000178 & 0,000279 \\
\hline 25 & MNCN & 0,000489 & 0,000792 & 0,029641 & 1,398949 & 0,000126 & 0,000615 \\
\hline 26 & BMRI & 0,000484 & 0,000812 & 0,022748 & 1,452899 & 0,000119 & 0,000233 \\
\hline 27 & UNTR & 0,00047 & 0,000609 & 0,023158 & 1,064544 & 0,000101 & 0,000383 \\
\hline 28 & CPIN & 0,000407 & 0,000796 & 0,030442 & 1,690541 & $-9,5 E-06$ & 0,000541 \\
\hline 29 & EXCL & 0,000239 & 0,000281 & 0,023307 & 0,722038 & $-6,3 E-05$ & 0,000473 \\
\hline 30 & SMGR & 0,000174 & 0,000361 & 0,022461 & 1,448072 & $-0,00033$ & 0,000222 \\
\hline 31 & ASII & 0,0001 & 0,000245 & 0,021475 & 1,354225 & $-0,0004$ & 0,000214 \\
\hline 32 & ANTM & $2,3 E-05$ & 0,000126 & 0,024474 & 0,744445 & $-0,00023$ & 0,000524 \\
\hline 33 & ASRI & $1,49 \mathrm{E}-05$ & 0,000135 & 0,033952 & 1,792568 & $-0,00072$ & 0,000719 \\
\hline 34 & GGRM & $4,06 \mathrm{E}-07$ & 0,000109 & 0,020323 & 0,968413 & $-0,00035$ & 0,000287 \\
\hline & & & & & & & \\
\hline
\end{tabular}

\section{Mencari nilai Cut-off point (Ci)}

Untuk mencari nilai cut-off point, ditentukan dulu alfa saham ke-i dan beta saham ke-i. Alfa saham ke-i dihitung berdasarkan nilai return ekspektasian, beta aktiva ke-i dan nilai excess return to beta aktiva ke-i. Kemudian mencari beta saham ke-i, dihitung berdasarkan nilai beta aktiva ke-i dan nilai excess return to beta aktiva ke-i. setelah itu baru ditentukan cut-off point dengan data jumlah alfa saham ke-i dan jumlah beta saham ke-i. Nilai cut-off point yang dipakai adalah nilai tertinggi yaitu sebesar 0,001068 yang diperoleh dari saham WSKT. Berikut hasil perhitungan untuk menentukan cutoff point. 
Atika Lusi Tania

Aplikasi Single Index Model.....

Tabel 6. Hasil perhitungan menentukan nilai cut-off point (Ci)

\begin{tabular}{|c|c|c|c|c|c|c|}
\hline No & Ket. & $\mathbf{A j}$ & $\sum \mathbf{A j}$ & $\mathbf{B j}$ & $\sum \mathbf{B j}$ & $\mathbf{C i}$ \\
\hline 1 & LPPF & 1,318725 & 1,318725 & 315,6375 & 315,6375 & 0,000171 \\
\hline 2 & INTP & 0,08472 & 1,403445 & 23,56382 & 339,2013 & 0,000181 \\
\hline 3 & LPKR & 0,162667 & 1,566112 & 72,10984 & 411,3111 & 0,0002 \\
\hline 4 & INCO & 1,574004 & 3,140116 & 734,255 & 1145,566 & 0,000367 \\
\hline 5 & PTPP & 6,588652 & 9,728768 & 3770,016 & 4915,582 & 0,000789 \\
\hline 6 & SCMA & 2,401624 & 12,13039 & 1444,789 & 6360,37 & 0,000881 \\
\hline 7 & TBIG & 0,954613 & 13,08501 & 593,3597 & 6953,73 & 0,000911 \\
\hline 8 & AALI & 0,984248 & 14,06925 & 634,7047 & 7588,435 & 0,000938 \\
\hline 9 & CTRA & 1,31168 & 15,38093 & 948,5231 & 8536,958 & 0,000964 \\
\hline 10 & PWON & 4,222646 & 19,60358 & 3299,181 & 11836,14 & 0,001018 \\
\hline 11 & TAXI & 1,948466 & 21,55205 & 1548,366 & 13384,5 & 0,001036 \\
\hline 12 & WIKA & 4,352179 & 25,90422 & 3662,459 & 17046,96 & 0,001059 \\
\hline 13 & WSKT & 5,685796 & 31,59002 & 5113,779 & 22160,74 & 0,001068 \\
\hline 14 & KLBF & 5,186416 & 36,77644 & 4996,325 & 27157,07 & 0,001064 \\
\hline 15 & $\mathrm{ADHI}$ & 3,821662 & 40,5981 & 3732,474 & 30889,54 & 0,00106 \\
\hline 16 & UNVR & 3,992553 & 44,59065 & 4409,147 & 35298,69 & 0,001044 \\
\hline 17 & PGAS & 2,039384 & 46,63004 & 2386,203 & 37684,89 & 0,001034 \\
\hline 18 & BBRI & 8,115739 & 54,74577 & 9845,868 & 47530,76 & 0,000996 \\
\hline 19 & BSDE & 3,794726 & 58,5405 & 4821,573 & 52352,33 & 0,000979 \\
\hline 20 & AKRA & 1,407897 & 59,9484 & 2062,499 & 54414,83 & 0,00097 \\
\hline 21 & BBNI & 6,146113 & 66,09451 & 9214,09 & 63628,92 & 0,00093 \\
\hline 22 & ICBP & 2,306373 & 68,40088 & 3596,489 & 67225,41 & 0,000916 \\
\hline 23 & BBCA & 4,589574 & 72,99046 & 8173,576 & 75398,99 & 0,000881 \\
\hline 24 & INDF & 1,647114 & 74,63757 & 2979,955 & 78378,94 & 0,00087 \\
\hline 25 & MNCN & 1,556219 & 76,19379 & 3184,097 & 81563,04 & 0,000856 \\
\hline 26 & BMRI & 4,387921 & 80,58171 & 9069,242 & 90632,28 & 0,000822 \\
\hline 27 & UNTR & 1,387985 & 81,9697 & 2955,456 & 93587,74 & 0,000812 \\
\hline 28 & CPIN & 2,147056 & 84,11675 & 5280,005 & 98867,74 & 0,000791 \\
\hline 29 & EXCL & 0,263353 & 84,3801 & 1102,414 & 99970,15 & 0,000786 \\
\hline 30 & SMGR & 1,648984 & 86,02909 & 9459,049 & 109429,2 & 0,000736 \\
\hline 31 & ASII & 0,860438 & 86,88953 & 8576,626 & 118005,8 & 0,000693 \\
\hline 32 & ANTM & 0,024335 & 86,91386 & 1057,186 & 119063 & 0,000687 \\
\hline 33 & ASRI & 0,066572 & 86,98043 & 4467,058 & 123530,1 & 0,000664 \\
\hline 34 & GGRM & 0,001328 & 86,98176 & 3272,831 & 126802,9 & 0,000648 \\
\hline
\end{tabular}

FINANSIA Vol. 01, No. 01, Januari - Juni 2019 


\section{Output}

Output adalah menentukan skala dari timbangan atas tiap-tiap saham (Zi) dan Proporsi aktiva ke-i (Wi). Nilai Zi ditentukan dengan nilai beta aktiva ke-i, nilai excess return to beta aktiva ke-i, dan nilai cut-off point. Sedangkan Wi ditentukan dengan membagi tiap-tiap nilai Zi dengan total Zi, pada akhirnya diperoleh persentase. Untuk Wi yang memiliki nilai dibawah cut-off point dihilangkan dari perhitungan. Jadi diperoleh 13 saham yang terbentuk portofolio optimal.

Tabel 7. Hasil Output

\begin{tabular}{|l|l|r|r|}
\hline No & \multicolumn{1}{|c|}{ Ket } & $\mathbf{Z i}$ & $\mathbf{W i}$ \\
\hline 1 & LPPF & 0,679415 & 0,088688 \\
\hline 2 & INTP & 0,525195 & 0,068557 \\
\hline 3 & LPKR & 0,381215 & 0,049762 \\
\hline 4 & INCO & 1,021118 & 0,133292 \\
\hline 5 & PTPP & 1,493161 & 0,194911 \\
\hline 6 & SCMA & 0,921155 & 0,120243 \\
\hline 7 & TBIG & 0,658216 & 0,085921 \\
\hline 8 & AALI & 0,558929 & 0,07296 \\
\hline 9 & CTRA & 0,304401 & 0,039735 \\
\hline 10 & PWON & 0,449881 & 0,058725 \\
\hline 11 & TAXI & 0,260578 & 0,034015 \\
\hline 12 & WIKA & 0,282793 & 0,036915 \\
\hline 13 & WSKT & 0,124694 & 0,016277 \\
\hline 14 & KLBF & $-0,1246$ & \\
\hline 15 & ADHI & $-0,1013$ & \\
\hline 16 & UNVR & $-0,60251$ & \\
\hline 17 & PGAS & $-0,54912$ & \\
\hline 18 & BBRI & $-1,59266$ & \\
\hline 19 & BSDE & $-0,89231$ & \\
\hline 20 & AKRA & $-0,77368$ & \\
\hline 21 & BBNI & $-2,5818$ & \\
\hline 22 & ICBP & $-1,47356$ & \\
\hline 23 & BBCA & $-3,67211$ & \\
\hline 24 & INDF & $-1,68498$ & \\
\hline 25 & MNCN & $-1,31869$ & \\
\hline & & & \\
\hline
\end{tabular}


Aplikasi Single Index Model.....

\begin{tabular}{|l|l|r|l|}
\hline 26 & BMRI & $-3,64727$ & \\
\hline 27 & UNTR & $-1,66155$ & \\
\hline 28 & CPIN & $-2,06598$ & \\
\hline 29 & EXCL & $-1,26608$ & \\
\hline 30 & SMGR & $-5,83839$ & \\
\hline 31 & ASII & $-6,12928$ & \\
\hline 32 & ANTM & $-1,48415$ & \\
\hline 33 & ASRI & $-2,6246$ & \\
\hline 34 & GGRM & $-3,60843$ & \\
\hline
\end{tabular}

\section{Hasil Proporsi Saham}

Setelah menghitung $\mathrm{Zi}$ dan $\mathrm{Wi}$, diperoleh proporsi saham dengan mengalikan dengan 100. Berikut ini adalah persentase saham yang diperoleh berdasarkan perhitungan Portofolio Single Indeks Model. Data tersebut menunjukkan bahwa proporsi saham terbesar adalah saham dengan kode PTPP yaitu 19,49\% dari PT. PP (Persero) Tbk. Saham dengan proporsi terkecil dengan kode WSKT yaitu 1,63\% dari PT. Waskita Karya (Persero) Tbk.

\section{Tabel 8. Proporsi Saham dengan Perhitungan Portofolio Single} Indeks Model

\begin{tabular}{|c|c|c|r|}
\hline No & AKTIVA & Wi & $\begin{array}{c}\text { Wi } \\
\text { (Pembulatan) }\end{array}$ \\
\hline 1 & LPPF & $8,87 \%$ & $9 \%$ \\
\hline 2 & INTP & $6,86 \%$ & $7 \%$ \\
\hline 3 & LPKR & $4,98 \%$ & $5 \%$ \\
\hline 4 & INCO & $13,33 \%$ & $13 \%$ \\
\hline 5 & PTPP & $19,49 \%$ & $19 \%$ \\
\hline 6 & SCMA & $12,02 \%$ & $12 \%$ \\
\hline 7 & TBIG & $8,59 \%$ & $9 \%$ \\
\hline 8 & AALI & $7,30 \%$ & $7 \%$ \\
\hline 9 & CTRA & $3,97 \%$ & $4 \%$ \\
\hline 10 & PWON & $5,87 \%$ & $6 \%$ \\
\hline 11 & TAXI & $3,40 \%$ & $3 \%$ \\
\hline 12 & WIKA & $3,69 \%$ & $4 \%$ \\
\hline 13 & WSKT & $1,63 \%$ & $2 \%$ \\
\hline \multicolumn{2}{|c|}{ Total } & $\mathbf{1 0 0 , 0 0 \%}$ & $\mathbf{1 0 0} \%$ \\
\hline
\end{tabular}




\begin{tabular}{|l|l|l|}
\hline Total & $100,00 \%$ & $100 \%$ \\
\hline
\end{tabular}

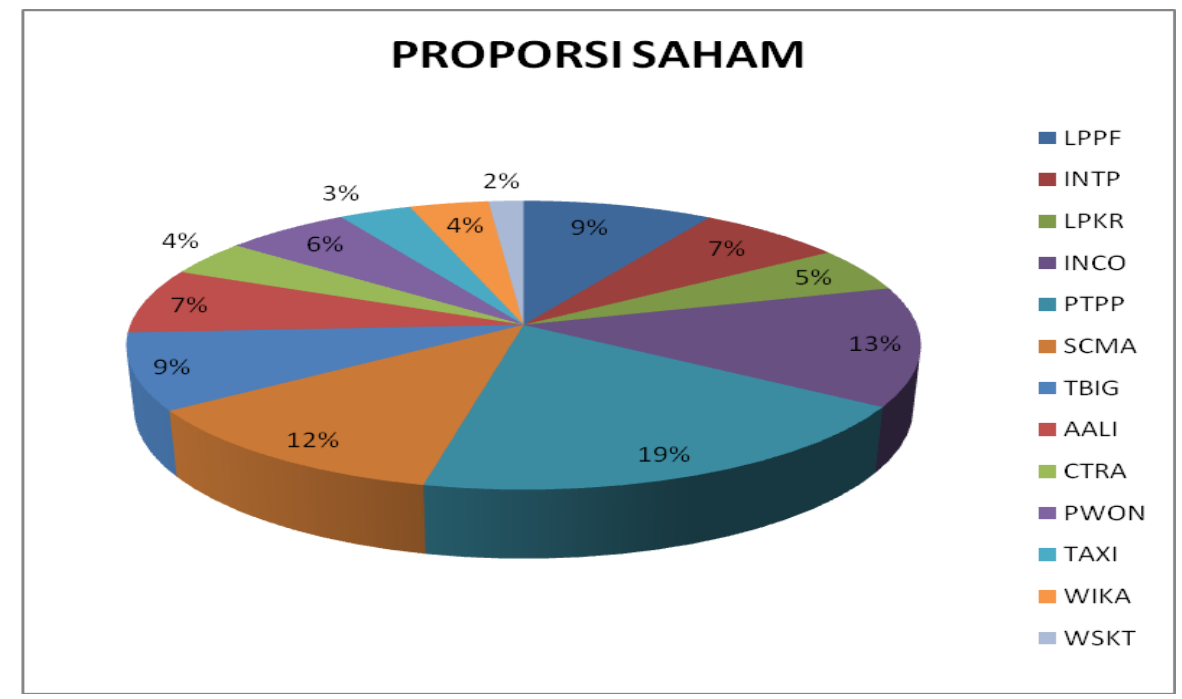

Grafik1. Hasil Proporsi Saham Portofolio Optimal dengan Single Index Model

\section{Total Rupiah Investasi Saham}

Setelah ditentukan proporsi saham yang akan dibeli oleh investor, ditentukan jumlah rupiah disesuaikan dengan dana yang dimiliki dan jumlah lembar saham yang akan dibeli. Berikut ini adalah perhitungan rupiah dan jumlah saham yang akan dibeli. Misal jumlah rupiah yang akan diinvestasikan sejumlah Rp 1.000.000,00 (satu juta rupiah), maka jumlah lambar dan proporsi saham yang akan dibeli adalah sebagai berikut.

Tabel 9. Hasil perhitungan jumlah lembar saham yang akan dibeli

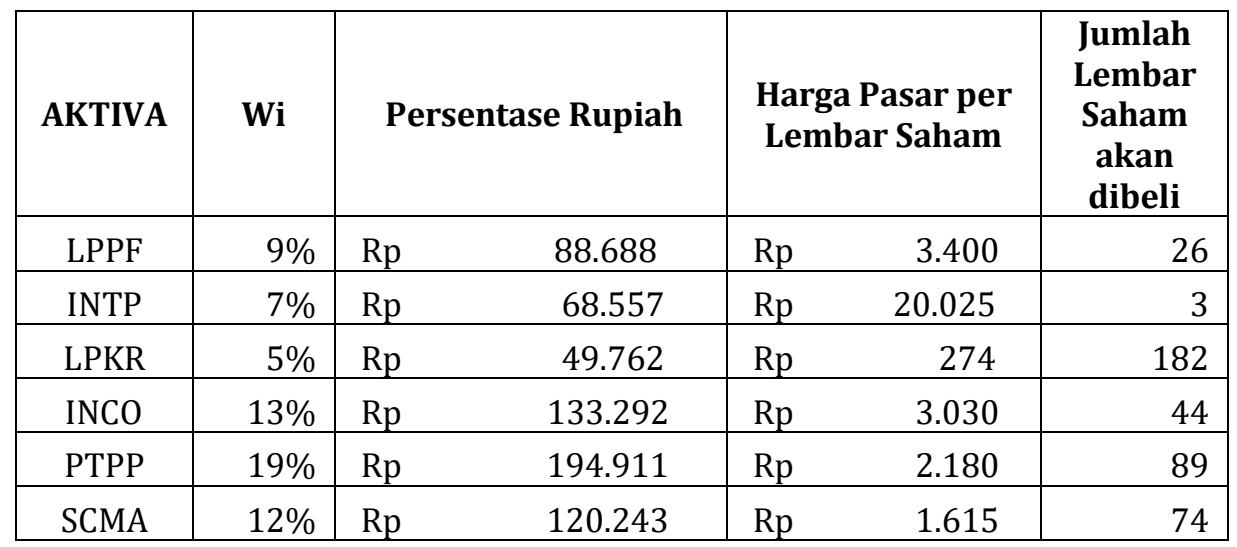




\begin{tabular}{|c|r|lr|lr|r|}
\multicolumn{2}{|c}{ Atika Lusi Tania } \\
TBIG & $9 \%$ & $\mathrm{Rp}$ & 85.921 & $\mathrm{Rp}$ & 3.850 & 22 \\
\hline AALI & $7 \%$ & $\mathrm{Rp}$ & 72.960 & $\mathrm{Rp}$ & 10.350 & 7 \\
\hline CTRA & $4 \%$ & $\mathrm{Rp}$ & 39.735 & $\mathrm{Rp}$ & 1.070 & 37 \\
\hline PWON & $6 \%$ & $\mathrm{Rp}$ & 58.725 & $\mathrm{Rp}$ & 725 & 81 \\
\hline TAXI & $3 \%$ & $\mathrm{Rp}$ & 34.015 & $\mathrm{Rp}$ & 50 & 680 \\
\hline WIKA & $4 \%$ & $\mathrm{Rp}$ & 36.915 & $\mathrm{Rp}$ & 2.340 & 16 \\
\hline WSKT & $2 \%$ & $\mathrm{Rp}$ & 16.277 & $\mathrm{Rp}$ & 1.970 & 8 \\
\hline TOTAL & $\mathbf{1 0 0} \%$ & $\mathbf{R p}$ & $\mathbf{1 . 0 0 0 . 0 0 0}$ & & & $\mathbf{1 2 7 1}$ \\
\hline
\end{tabular}

\section{KESIMPULAN}

Berdasarkan hasil analisis data menggunakan Portofolio Optimal metode Single Index Model, diperoleh hasil bahwa dari 45 saham dalam LQ45 diperoleh 13 saham optimal yang akan dibeli oleh investor. Tiga belas saham dan harga pasar tersebut antara lain LPPF Rp3.400, INTP Rp20.025, LPKR Rp274, INCO Rp3.030, PTPP Rp2.180, SCMA Rp1.615, TBIG Rp3.850, AALI Rp10.350, CTRA Rp1.070, PWON Rp725, TAXI Rp50, WIKA Rp2.340, dan WSKT Rp1.970. Proporsi saham yaitu LPPF 9\%, INTP 7\%, LPKR 5\%, INCO 13\%, PTPP 19\%, SCMA $12 \%$, TBIG 9\%, AALI 7\%, CTRA 4\%, PWON 6\%, TAXI 3\%, WIKA $4 \%$, WSKT 2\%. Dana yang akan diinvestasikan Rp 1.000.000, maka jumlah lembar saham total yang akan dibeli adalah 1.271 lembar, atau jika dalam jumlah lot sekitar 12 lot.

\section{E. DAFTAR PUSTAKA}

Abbas, Valadkhani, Surachai Chancharat, and Charles Harvie. "A Factor Analysis of International Portfolio Diversification" 25, no. 3 (2008): 10.

"BI 7-Day Repo Rate Data - Bank Sentral Republik Indonesia." Accessed July 2, 2019. https://www.bi.go.id/en/moneter/bi7day-RR/data/Contents/Default.aspx.

Bodie, ZVI, Alex Kane, and Marcus Alan J. Investment. Eight Edition. Singapure: Irwin/Mc Graw Hill, 2009.

Hartono, Jogiyanto. Metodologi Penelitian Bisnis, Salah Kaprah Dan Pengal Aman-Pengalaman. Yogyakarta: BPFE-Yogyakarta, 2013.

- - C. Teori Dan Praktik Portofolio Dengan Excel. Jakarta: Salemba Empat, 2014. 
- - Teori Portofolio Dan Analisis Investasi (Edisi Kedelapan). Yogyakarta: BPFE, 2013.

Jones, Charles P. Analysis and Management. Ninth edition. United States: John Wiley\&Sons, Inc, 2004.

Mediatama, Grahanusa. "Investor pasar modal per Maret 2018 meningkat 8,34\%." kontan.co.id, April 20, 2018. http://investasi.kontan.co.id/news/investor-pasar-modal-permaret-2018-meningkat-834.

Oktaviani, and Wijayanto. "Aplikasi Single Index Model Dalam Pembentukan Portofolio Optimal Saham LQ45 Dan Jakarta Islamic Index" 4 (1) (2015). http://maj.unnes.ac.id.

"PT Bursa Efek Indonesia." PT Bursa Efek Indonesia. Accessed July 2, 2019. http://www.idx.co.id.

Septyanto, and Kertopati. "Portofolio Saham Dengan Model Markowitz Dan Single Index Model Pada Saham-Saham Yang Terdaftar Pada LQ45” 16 No. 2 (Desember 2014). 